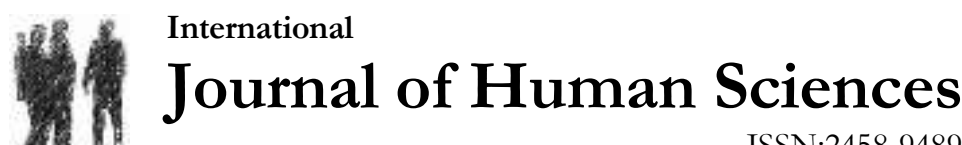 \\ ISSN:2458-9489
}

Volume 14 Issue 4 Year: 2017

\section{Investigation of the role of parent attitudes, SES and religiosity in university students' discriminative attitudes ${ }^{1}$}

\author{
İdris Y1lmaz ${ }^{1}$ \\ Fatih Koca ${ }^{2}$ \\ Akın Çelik ${ }^{3}$
}

\begin{abstract}
The goal of the current study is to examine the role of parental attitudes, social economic status, and individuals' religious beliefs in university students' attitudes towards gender, racial, religious, and homosexual discrimination. The sample of the study consisted of 643 (408 male and 335 female) university students attending Sport Science and Physical Education programs in large urban public universities in Turkey. Demographic questionnaire and Discriminative Attitudes inventory were employed. Multiple regression was applied to understand and document the predictive role of the study variables in the participants' homosexual discriminative attitudes. The researchers found that perceived parental attitudes and religiosity had statistically group differences in the individuals' discriminatory attitudes. Moreover, the findings indicated that parental attitudes, social economic status, and religious belief were significant predictors of university students' attitudes towards homosexuality. The study implications and future directions were discussed.
\end{abstract}

Keywords: Homosexual discrimination; parental attitudes; social economic status; religious belief.

\section{Introduction}

Discrimination refers to prejudiced or an example of discriminating categorically rather than individually because of religious belief, gender, sexual preference, and race (e.g., Basar \& Oz, 2016; Cabuk, 2010; Jackson, Johnson, \& Roberts, 2008; Meyer, 2007). In fact, psychological well-being associated with discrimination is claimed that have a direct and indirect effect on the development of psychological and sociological problems within the individual in any society. Thus, in recent years, researchers have increasingly examined the nature of inequalities in the areas of gender, race, ethnicity, religion, and sexual preferences ( Davis, 2008; Perry, Harp, \& Oser, 2013). For instance, Hunler (2013) pointed out that negative attitudes toward woman and gender discrimination are associated with higher level of depression among Turkish women. Furthermore, Celik, Pasinoglu, Tan, and Koyuncu (2015) examined the university students' attitudes about gender equality and the findings indicated that health science students have more positive perceptions regarding gender

\footnotetext{
1 The current study was partially presented in World Health Sport Tourism Congress \& Exhibition (HESTROUREX), Üniversite Öğrencilerinin Eşcinsel Ayrımcılıklarının Aile Tutumları, Sosyal Ekonomik Statü ve Dini İnanç Yoğunluğu Açısından İncelenmesi, Antalya, Turkey, and 6-9 April 2017.

2 Assistant Professor Dr., Karadeniz Technical University, Physical Education and Sport Science, idrisyilmaz@ktu.edu.tr.

3 Associate Professor Dr., Karadeniz Technical University, Educational Sciences, Guidance and Psychological Counselling, fkoca@ktu.edu.tr

${ }^{3}$ Assistant Professor Dr., Karadeniz Technical University, Physical Education and Sport Science, akincelik@ktu.edu.tr.
} 
Yilmaz, I.., Koca, F.., \& Celik, A. (2017). Investigation of the role of parent attitudes, SES and religiosity in university students' discriminative attitudes. Journal of Human Sciences, 14(4), 3626-3633. doi:10.14687/jhs.v14i4.4762

equality. Accordingly, Alkan, Erdem, and Celik (2016) put forward that gender, race, religion, and belief systems might be source of discrimination in Turkey. However, there is a scarcity of educational research to understand and document the impact of social economic status, parental attitudes, and religiosity on the individuals' discriminative attitudes toward some people different than others because of some of their characteristics or belief systems in Turkey. Although, very little attention was paid to ethnic, regional, and religious identity in Turkish culture, Turkey has a religiously and an ethnically diverse identity. Moreover, the leading forces for change on Turkish culture are Islam and nationalism, therefore it might be interesting to examine how Turkish university students' attitudes toward discrimination.

Individuals of stigmatized groups, including woman, African American, homosexuals, experience poor outcomes across a wide variety of educational and social contexts. For instance, Sidanius and Pratto (1999) pointed out that African Americans and Mexicans might face discrimination across their educational, social, and work lives. Women, unfortunately, continue to face various difficult barriers across key life domains including family, work, and education (Barreto, Ryan, \& Schmitt, 2008). For the religious belief, perceived group discrimination and negative ethno-religious attitudes toward Muslim community in western cultures might lead to inequalities and economic disadvantages among Muslims (Cheung, 2014; Connor \& Koenig, 2013). Unfortunately, Muslims tend to lower rates of labor force and chance of occupational attainment. Furthermore, Awad (2010) investigated the role of acculturation, ethnic identity, and religious affiliation on perceived discrimination for Arab and Middle Eastern people in the US. The study findings showed that Muslims with high level of dominant society immersion were exposed to the most ethnic and religious discrimination. Strikingly, Lehrer (2004) posited that religious affiliation might be a significant indicator of economic and demographic outcomes in American culture and therefore, religious involvement in the dominant belief system (Christianity) has usually crucial effects on health and economic well-being. Similarly, parents' ethnic-racial and religious socialization practices play a role in transmission of information, values, and perspectives about ethnicity, race, and religion to their children. Furthermore, negative parental doctrines and socialization process deteriorate their children's negative attitudes toward any discrimination (Hughes et al., 2006).

Homosexuality refers to sexual desire, attractions or behavior directed toward individual of one's own sex (Sahin \& Bilgic, 2016; Yilmaz \& Demirbas, 2015). Nowadays, homosexuality is not considered as an illness by most psychologists and scientists. Accordingly, the American Psychiatry Association and the World Health Organization excluded homosexuality from their lists of illnesses in late $20^{\text {th }}$ century (Cabuk, 2010). Although extensive biological and psychological researches indicated that homosexuality as an inmate drive is not a disorder, negative attitudes towards gay relationships is still growing (e.g., Lombardi, Wilchins, Priesing, \& Malouf, 2001; Jackson, Johnson, \& Roberts, 2008; Meyer, 2007). In fact, both cultural norms, parental rearing, and economical difficulties might be a result of a larger social climate that severely sanctions the individuals for not conforming to the dominant society's values regarding sexual preferences. Homosexuality is popular topic within many fields of research in western countries, but few discuss the role of parent, SES, and religious belief in the individuals' attitudes towards homosexuality in Turkey. Accordingly, lesbians, gays, and bisexuals might vary in social economic status, cultural identity, age, education, religious belief, parental rearing, and their rejection or acceptance of societal prejudges against homosexuality (Lombardi et al., 2001). Unfortunately, although homosexuality started to be discussed in the mid-1980s (Cabuk, 2010; Goregenli, 2004), homophobia is still very controversial and common issue in Turkish culture and negative attitudes and stereotypic prejudices against could lead to serious psychological and sociological problems for them and the whole society. Attitudes toward homosexuality have become hot-button issues in contemporary politics and society; however there is little known about personal dynamics drive such attitudes, including parenting (Weinstein \& Ryan, 2015). In fact, parents, who are perceived as supporting autonomy, may convey to their children that love and affection is not dependent on the cultural climate, their 
Yilmaz, I.., Koca, F.., \& Celik, A. (2017). Investigation of the role of parent attitudes, SES and religiosity in university students' discriminative attitudes. Journal of Human Sciences, 14(4), 3626-3633. doi:10.14687/jhs.v14i4.4762

preferences, and sexual orientation (Chirkow \& Ryan, 2001). The success to support autonomy often contributes to higher well-being (Assor, Kaplan, \& Roth, 2002). Unfortunately, even autonomy supportive parents in western culture are often reported at least some degree of negativity and maladaptive attitudes towards homosexuality (Savin-Williams \& Ream, 2003). In fact, being rejected or stigmatized by parents or important others more likely to contributes to an increase in their children's negative attitudes towards gay and lesbians (Legate, Ryan, \& Weinstein, 2011). Industrialized countries have, in recent years, shown increasing support and respect for gay, lesbian, and bisexual rights. However, despite the growing support, there is still little known about how social economic status affects the individuals' attitudes towards the homosexuality. Previous research indicated that the indicators of middle and upper-class status, including higher levels of education and income, are significantly related to more positive social attitudes towards the samesex marriages and the homosexuality in western cultures (e.g., Lee \& Chou, 2017; Nowosielski, Kurpisz, Lew-Starowicz, \& Samochowiec, 2016). Similarly, Perry and collogues (2015) examined the role of ethnicity and SES in the individuals' attitudes towards the homosexuality. They found that the effect of social economic status is statistically significant predictor and higher or upper class individuals are more likely to support the right to have the same-sex marriages and show more acceptance and less rejection than those from lower class backgrounds. Despite recent developments in the direction of LGBT equality in western countries, homosexuality is not widely accepted by religious communities across world (Moreira, 2007). In fact, religious groups representing a huge group vocal faction debate over the homosexuality issues. The linkage between homosexuality and religion has received continued attention from researchers and politicians. Extensive number of research pointed out that frequent attendance at religious places and a commitment to conservative theological view in any belief system are markers of more restrictive and castigatory standings on LGBT and same-sex marriages (e.g., Adamczyk \&Pitt, 2009; Correa, 2010; Ogland \& Verona, 2014; Olson, Cadge, \& Harrison, 2006). Accordingly, Moon (2002) claimed that a moral-philosophical-theological viewpoint often tries to locate the basis for homonegativity within the holy writings of religions, including Islam. However, we are little known about the religious denomination of an individual and his/her religiosity to explain her/his attitudes toward the homosexual discrimination.

\section{Summary of research questions and hypothesis}

The goal of the study was summarized by the following research questions:

1. Does the individuals' discriminatory attitudes vary as a function of perceived parental attitudes?

2. Does the individuals' discriminatory attitudes vary as a function of social economic status?

3. Does the individuals' discriminatory attitudes vary as a function of religiosity?

\section{Method}

\section{Participants}

The study participants included a group of 643 (408 male ; 335 female) Physical Education and Sport Science students in four large urban city universities in Turkey.All participants were born in Turkey and were Turkish-speaking. The participants' mean age was 19.87 (SD = 2.93).

\section{Procedures}

Participants voluntarily took part in the current study and the researchers asked them to rate report their percetions regarding the gender, ethnic, religious, homosexual discrimination and demographic information (e.g., age, gender, parent attitudes, religiousness, and income).

\section{Instruments}

Discrimination scale (Vural \& Gomleksiz, 2010) is a 21-item self-report measure that is used to assess the individuals' discriminatory attitudes toward gender, homosexuality, race, and religion. It uses a 6-point Likert format, which ranges from "totally disagree" (1) to "totally agree (6). This scale consists of four subscales: gender discriminatory (7-item) attitudes, homosexuality discriminatory attitudes (7-item), race discriminatory attitudes (4-item), and religion discriminatory 
Yilmaz, I.., Koca, F.., \& Celik, A. (2017). Investigation of the role of parent attitudes, SES and religiosity in university students' discriminative attitudes. Journal of Human Sciences, 14(4), 3626-3633. doi:10.14687/jhs.v14i4.4762

attitudes (3-item). The scale has demonstrated good reliability across all scales: for the total .91, gender, .82, homosexuality, .84, race, .79, and religion, .83. The instrument has also showed acceptable evidence for concurrent and constructs validity across extensive research studies.

\section{Data Analysis}

The correlational research design was employed in the current research. Parenting style, SES, and Religiosity differences were examined using independent sample t-test and ANOVA. The alpha level was set at .05. The researchers also conducted multiple regression method to examine the role of parental attitudes, SES, and religiosity in the individual's discriminatory attitudes.

\section{Results}

The researchers found that there was a statistically significant perceived parental attitude group effect on the individuals' general discriminatory attitudes $(F(3,642)=9.62, p<.05)$. For the discriminatory attitudes toward gender discrimination, there was a statistically significant group mean differences $(F(3,642)=14.73, p<.05)$. However, the results did not find any statistically significant group effect on the sub-scale of race, homosexuality, and religion discrimination (see Table 1). More specifically, authoritarian parental attitudes $(\mathrm{M}=4.06, \mathrm{SD}=.06)$ had more discriminatory attitudes than democratic type $(\mathrm{M}=2.07, \mathrm{SD}=.08)$, permissive $(\mathrm{M}=2.09, \mathrm{SD}=.05)$, and uninvolved $(\mathrm{M}=2.30, \mathrm{SD}=.04)$. We also examined the impact of social economic status on the participants' discriminatory attitudes. Based on the findings, there was not any statistically significant mean difference in terms of SES on discriminatory attitudes toward gender, homosexuality, race, and religion (see Table 2). Interestingly, the participants with high social economic status $(\mathrm{M}=2.99, \mathrm{SD}=.06)$ had more negative discriminatory attitudes toward race/ethnicity than that of the middle $(M=2.81, S D=.05)$ and low SES group $(M=2.91, S D=.06)$. For the religiosity, the individuals with strong religious belief group showed statistically less discriminatory attitudes toward race $(t(1,642)=-2.87, p<.05)$ and religion $(t(1,642)=-3.08$, $p<.05)$ discrimination than the participants with low or non-religious believers. However, the religiously conservative group showed more discriminatory attitudes toward homosexuality $(\mathrm{M}=3.68, \mathrm{SD}=.08)$ and gender $(\mathrm{M}=3.37, \mathrm{SD}=.06)$ than low or non-believer group's attitudes toward homosexuality $(\mathrm{M}=3.06, \mathrm{SD}=.06)$ and gender $(\mathrm{M}=2.11, \mathrm{SD}=.03)$. Therefore, as expected, there was a statistically significant difference between religious and non-religious group in terms of homosexuality $(t(1,642)=3.39, p<.05)$ and gender $(t(1,642)=2.84, p<.05)$. In addition, religious $(\mathrm{M}=2.94, \mathrm{SD}=.05)$ and non-religious group $(\mathrm{M}=3.07, \mathrm{SD}=.08)$ were statistically significant different from each other in terms of overall discriminatory attitudes $(t(1,642)=2.26 p<.05)$.

Table 1

One-Way Analysis of Variance of Discriminatory Attitude Scores by Perceived Parental Attitudes

\begin{tabular}{|c|c|c|c|c|c|}
\hline Source & $\begin{array}{l}\text { Parental } \\
\text { Attitudes }\end{array}$ & Mean & $S D$ & $F$ & $p$ \\
\hline \multirow[t]{4}{*}{ Discriminatory Attitude Total } & Democratic & 2.07 & 0.08 & 9.62 & $0.00 * *$ \\
\hline & Permissive & 2.09 & 0.05 & & \\
\hline & Uninvolved & 2.30 & 0.04 & & \\
\hline & Authoritative & 4.06 & 0.06 & & \\
\hline \multirow[t]{4}{*}{ Gender Discrimination } & Democratic & 2.07 & 0.08 & 14.73 & $0.00 * *$ \\
\hline & Permissive & 2.09 & 0.05 & & \\
\hline & Uninvolved & 2.30 & 0.04 & & \\
\hline & Authoritative & 4.06 & 0.06 & & \\
\hline \multirow[t]{4}{*}{ Homosexuality } & Democratic & 2.63 & 0.09 & 8.41 & $0.00^{* *}$ \\
\hline & Permissive & 2.67 & 0.08 & & \\
\hline & Uninvolved & 3.04 & 0.06 & & \\
\hline & Authoritative & 4.11 & 0.07 & & \\
\hline \multirow[t]{4}{*}{ Race/Ethnicity } & Democratic & 1.79 & 0.07 & 0.09 & 0.96 \\
\hline & Permissive & 2.02 & 0.06 & & \\
\hline & Uninvolved & 2.13 & 0.07 & & \\
\hline & Authoritative & 2.89 & 0.06 & & \\
\hline
\end{tabular}


Yilmaz, I.., Koca, F.., \& Celik, A. (2017). Investigation of the role of parent attitudes, SES and religiosity in university students' discriminative attitudes. Journal of Human Sciences, 14(4), 3626-3633. doi:10.14687/jhs.v14i4.4762

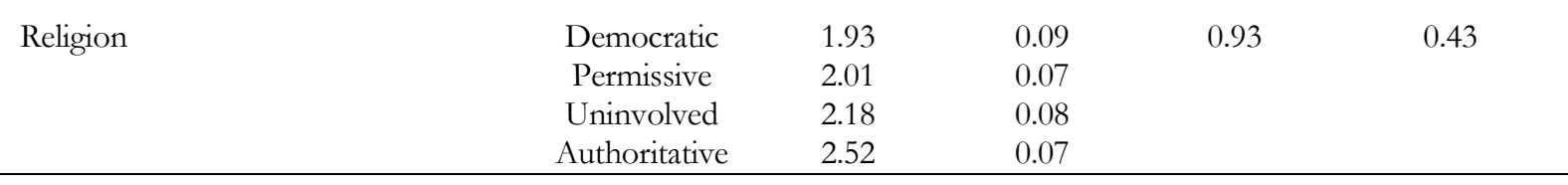

Table 2

One-Way Analysis of Variance of Discriminatory Attitude Scores by Social Economic Status (SES)

\begin{tabular}{|c|c|c|c|c|c|}
\hline Source & SES Group & Mean & $S D$ & $F$ & $p$ \\
\hline \multirow[t]{3}{*}{ Discriminatory Attitude Total } & Low & 2.91 & 0.06 & 1.63 & 0.19 \\
\hline & Middle & 2.81 & 0.05 & & \\
\hline & High & 2.99 & 0.06 & & \\
\hline \multirow[t]{3}{*}{ Gender Discrimination } & Low & 2.71 & 0.07 & 0.99 & 0.37 \\
\hline & Middle & 2.27 & 0.05 & & \\
\hline & High & 2.78 & 0.09 & & \\
\hline \multirow[t]{3}{*}{ Homosexuality } & Low & 2.73 & 0.08 & 0.68 & 0.51 \\
\hline & Middle & 2.91 & 0.05 & & \\
\hline & High & 3.06 & 0.07 & & \\
\hline \multirow[t]{3}{*}{ Race/Ethnicity } & Low & 2.67 & 0.06 & 2.15 & 0.06 \\
\hline & Middle & 2.42 & 0.05 & & \\
\hline & High & 2.39 & 0.06 & & \\
\hline \multirow[t]{3}{*}{ Religion } & Low & 2.53 & 0.09 & 0.88 & 0.42 \\
\hline & Middle & 2.02 & 0.05 & & \\
\hline & High & 2.16 & 0.06 & & \\
\hline
\end{tabular}

After examining the group effects on the discriminatory attitudes, we also conducted a multiple regression to examine the role of perceived parental attitudes, SES, and religiosity in the individuals' discriminatory scores. The current study's findings indicated that perceived parental attitudes, SES, and religiosity statistically and significantly predicted the participants' general discriminatory attitudes $(\mathrm{R} 2=.29, \mathrm{~F}(3,642)=4.57, \mathrm{p}<.01)$. It was found that perceived parental attitudes significantly predicted discriminatory attitudes $(\beta=.34, \mathrm{p}<.001)$, as did religiosity $(\beta=.16$, $\mathrm{p}<.001)$; however SES was not a significant predictor $(\beta=-.09, \mathrm{p}=0.11)$. The results of the regression indicated the three predictors explained $27.6 \%$ the variance.

Table 3

Multiple Regression Results of Discriminatory Attitude Scores by the Study Variables

\begin{tabular}{lcccc}
\hline Variable & $B$ & SE B & $\beta$ & $p$ \\
\hline Perceived Parental Attitudes & 1.86 & 0.82 & 0.34 & $0.00^{* *}$ \\
Religiosity & 1.02 & 0.51 & 0.16 & $0.00^{* *}$ \\
SES & 0.34 & 0.19 & -0.09 & 0.11 \\
R2 & 0.29 & & & \\
F $(3,642)=4.57$ & & & & $0.00^{* *}$ \\
\hline
\end{tabular}

\section{Discussion and Implications}

The goal of the study was to examine the role of perceived parental attitudes, SES, and religiosity in the sport science students' discriminatory attitudes. Accordingly, we also scrutinized how the participants' attitudes toward gender, homosexual, race, and religion discrimination vary by the variables indicated above. As expected, the participants' discriminatory attitudes statistically significantly varied by their perceived parental attitudes. Consistent with the literature, parental perceptions of children's abilities, cultural norms, and parental doctrines are impactful ingredients of the individuals' socialization process (e.g., Cheung, 2014; Connor \& Koenig, 2013). In fact, autonomy supportive and democratic parental attitudes might convey to their children love and affection and healthy socialization process (Assor, Kaplan, \& Roth, 2002). Negative parental 
Yilmaz, I.., Koca, F.., \& Celik, A. (2017). Investigation of the role of parent attitudes, SES and religiosity in university students' discriminative attitudes. Journal of Human Sciences, 14(4), 3626-3633. doi:10.14687/jhs.v14i4.4762

attitudes toward gender, ethnic, homosexuality, and religion discrimination may increase their children's hate and intolerance and therefore, their psychological well-being deteriorate rapidly (Alkan, Erdem, \& Celik, 2016). In the current study, after testing each sub-domains of discriminatory attitudes, we only observed the group differences in gender discrimination for parental attitudes Consistent with previous research, parental gender roles and attitudes are significantly linked to young adults' attitudes toward gendered family role, housework allocation (Cunningham, 2001; Williams, Radin, \& Allegro, 1992). Accordingly, youth with fathers, who are highly involved in childrearing practices, hold less stereotypical thoughts and perceptions regarding gender discrimination that the individuals with authoritative fathers (Blair, 1992). Inconsistent with the previous research (e.g., Sinclair, Dunn, \&Lowery, 2005), we did not find any significant group differences in homosexual, ethnic, and religion discrimination. This might be because, sport science students have more positive perceptions regarding homosexuality and negative attitudes toward ethnic and religion discrimination (Celik, Pasinoglu, Tan, \& Koyuncu, 2015). In addition, Turkish culture are not welcome to prejudicial discriminatory thoughts and attitudes toward religion and ethnicity because of religious and normative belief system in society.

Research findings also indicated that the role of social economic status in discriminatory attitudes, in consistent with the previous studies (Simons, Simons, \& Burt, 2006), there was not any statistical group differences. However, students with high social economic status had more discriminatory attitudes than middle and low group. For instance, parents with high SES provides more supportive and affection to their children, and so supportive parenting reduces the individuals' discriminatory attitudes toward gender, race, and homosexuality (Brown \& Bigler, 2004). Accordingly, Latino immigrant children in White and high SES community hold positive and important ethnic identities and perceived very low rates of discrimination (Brown \& Chu, 2012).

For religiosity, we examined how religious and non-religious sport sciences students' perceptions of discrimination changes. Results showed that religious and conservative participants showed less discriminative attitudes toward race; however, as expected, they had more prejudicial discriminative perceptions of homosexuality and gender than low or non-religious group. Similarly, Arnd and Bruin (2006) examined the impact of gender and religiosity on negative attitudes toward lesbians and gay men in South Africa. They found that gender and religiosity play a significant role in attitudes on homosexuality. In other words, male students had more negative prejudicial thoughts and perceptions regarding homosexuals. Furthermore, there was a consistent tendency for male and religious students to express more hostile attitudes towards lesbians and gays than female and non-conservative group. Societal values, as characterized by religion, are crucial dynamics linked to the formation of prejudicial attitudes and stereotypes about specific groups (Thomas \& Greiner, 1996). In this sense, religious fundamentalist groups are quite highly correlated with religious ethnocentrism and higher degrees of hostility toward homosexuals and gender, racialethnic minorities (Altemeyer, 2009). In addition, as Adamczyk and Pitt (2009) posited, crossnational differences in cultural orientations might explain the role of religion in the linkage between homosexual and gender attitudes and a society's cultural context. Namely, Turkish culture has dominantly collectivistic and conservative background and therefore, the notion of homosexuality and gender might be different from the individualistic culture, including American and European. Unfortunately, most women in Islamic society have to struggle for human rights and gender equality and so it is expected to have some prejudicial attitudes toward gender roles in a given culture. As shown in regression model, parental attitudes, social economical background, and religiosity are key factors to explain the individual's prejudicial discriminatory attitudes toward specific group of people in Turkey. In addition, the current sample consisted of sport science students and therefore as expected, their prejudicial attitudes towards racial and homosexual discriminatory attitudes were low. Similarly, Roper and Halloran (2007) conducted a study to explore male and female student athletes' attitudes toward homosexuality. Findings showed that there were no significant differences in their attitudes toward lesbians and gays. Moreover, they 
Yilmaz, I.., Koca, F.., \& Celik, A. (2017). Investigation of the role of parent attitudes, SES and religiosity in university students' discriminative attitudes. Journal of Human Sciences, 14(4), 3626-3633. doi:10.14687/jhs.v14i4.4762

reported that having contact with homosexual athletes helped them to develop more positive attitudes toward gay men and lesbians.

It is crucial to address the current study's limitations and the future recommendations. We need to be cautious regarding the generalizability of the research findings because the current sample only consisted of sport science college students. Furthermore, future researchers may want to consider include the need to not only examine the demographic factors, but also various psychological variables including empathy. In addition, it is crucial to investigate how discriminatory attitudes may influence the individuals' psychological well-being. In educational context, we need to help the students to develop positive attitudes toward special population.

\section{References}

Adamczyk, A., \& Pitt, C. (2009). Shaping attitudes about homosexuality: The role of religion and cultural context. Social Science Research, 38, 338-351.

Akar-Vural, R., \& Gömleksiz, M. (2010). Us and others: a study on prospective classroom teachers' discriminatory attitudes. Egitim Arastirmalari-Eurasian Journal of Educational Research, 38, 216 233.

Alkan, A., Erdem, R., \& Çelik, R. (2016). Sağlık Alanındaki Ayrımcı Tutum ve Davranışlar: Kavramsal Bir İnceleme. Hacettepe Sağhle İdaresi Dergisi, 19(3).

Arndt, M., \& De Bruin, G. (2006). Attitudes toward lesbians and gay men: Relations with gender, race and religion among university students. Psychology in Society, 33, 16-30.

Assor, A., Kaplan, H., \& Roth, G. (2002). Choice is good, but relevance is excellent: Autonomyenhancing and suppressing teacher behaviours predicting students' engagement in schoolwork. British Journal of Educational Psychology, 72(2), 261-278.

Awad, G. H. (2010). The impact of acculturation and religious identification on perceived discrimination for Arab/Middle Eastern Americans. Cultural Diversity and Ethnic Minority Psychology, 16(1), 59.

Barreto, M. E., Ryan, M. K., \& Schmitt, M. T. (2008). The glass ceiling in the 21st century: Understanding barriers to gender equality. American Psychological Association.

Başar, K., Öz, G., \& Karakaya, J. (2016). Perceived discrimination, social support, and quality of life in gender dysphoria. The journal of sexual medicine, 13(7), 1133-1141.

Brown, C. S., \& Chu, H. (2012). Discrimination, ethnic identity, and academic outcomes of Mexican immigrant children: The importance of school context. Child development, 83(5), 1477-1485.

Burt, C. H., Simons, R. L., \& Simons, L. G. (2006). A longitudinal test of the effects of parenting and the stability of self-control: negative evidence for the general theory of crime. Criminology, 44(2), 353-396.

Cheung, S. Y. (2014). Ethno-religious minorities and labour market integration: generational advancement or decline?. Ethnic and Racial Studies, 37(1), 140-160.

Chirkov, V. I., \& Ryan, R. M. (2001). Parent and teacher autonomy-support in Russian and US adolescents: Common effects on well-being and academic motivation. Journal of cross-cultural psychology, 32(5), 618-635.

Connor, P., \& Koenig, M. (2013). Bridges and barriers: religion and immigrant occupational attainment across integration contexts. International Migration Review, 47(1), 3-38.

Correa, S. (2010). Brazil: One of the abortion front lines. Reproductive Health Matters, 18(36), 111-117

Cunningham, M. (2001). The influence of parental attitudes and behaviors on children's attitudes toward gender and household labor in early adulthood. Journal of Marriage and family, 63(1),111-122. 
Yilmaz, I.., Koca, F.., \& Celik, A. (2017). Investigation of the role of parent attitudes, SES and religiosity in university students' discriminative attitudes. Journal of Human Sciences, 14(4), 3626-3633. doi:10.14687/jhs.v14i4.4762

Çabuk, D. (2010). T.C tıp öğrencileri ve hekimlerin eşcinsellik hakkındaki, tutumları ve gey ve lezbiyenlerin sağlık hizmeti deneyimleri. Uzmanlık tezi. Gazi Üniversitesi Tıp Fakültesi, Psikiyatri Ana Bilim Dalı, Ankara.

Çelik, A. S., Pasinlioğlu, T., Gonca, T. A. N., Koyuncu, H. Üniversite Öğrencilerinin Cinsiyet Eşitliği Tutumlarının Belirlenmesi. Florence Nightingale Hemşirelik Dergisi 2013;21(3):1816.

Gray, D. P., Kramer, M., Minick, P., McGehee, L., Thomas, D., \& Greiner, D. (1996). Heterosexism in nursing education. Journal of Nursing Education, 35(5), 204-210.

Göregenli, M. (2006). Gruplararası ilişki ideolojisi olarak homofobi. Kaos GL, Geylerin ve lezbiyenlerin sorunları ve toplumsal barış için çözüm arayışları içinde (142-148). Ankara: Kaos GL Kitapları.

Hunler, O. S. (2013). The relationship between gender role ideology and depression among female university students/Universite ogrencisi kadinlarda toplumsal cinsiyet ideolojisi ile depresyon iliskisi. Kadin/Woman 2000, 14(2), 39-54.

Jackson, N. C., Johnson, M. J., \& Roberts, R. (2008). The potential impact of discrimination fears of older gays, lesbians, bisexuals and transgender individuals living in small-to moderatesized cities on long-term health care. Journal of homosexuality, 54(3), 325-339.

Kurpisz, J., Mak, M., Lew-Starowicz, M., Nowosielski, K., Bieńkowski, P., Kowalczyk, R., ... \& Samochowiec, J. (2016). Personality traits, gender roles and sexual behaviours of young adult males. Annals of general psychiatry, 15(1), 28.

Lombardi, E. L., Wilchins, R. A., Priesing, D., \& Malouf, D. (2002). Gender violence: Transgender experiences with violence and discrimination. Journal of homosexuality, 42(1), 89-101.

Legate, N., Ryan, R. M., \& Weinstein, N. (2012). Is coming out always a "good thing"? Exploring the relations of autonomy support, outness, and wellness for lesbian, gay, and bisexual individuals. Social Psychological and Personality Science, 3(2), 145-152.

Lehrer, E. L. (2004). Religion as a determinant of economic and demographic behavior in the United States. Population and development review, 30(4), 707-726.

Meyer, I. H. (2007). Prejudice and discrimination as social stressors. In The health of sexual minorities (pp. 242-267). Springer US.

Ogland, C., \& Verona, A. P. (2011). Religion and attitudes toward abortion and abortion policy in Brazil. Journal for the Scientific Study of Religion, 50, 812-821.

Olson, L. R., Cadge W., \& Harrison, J. T. (2006). Religion and public opinion about same-sex marriage. Social Science Quarterly, 87, 340-360.

Perry, B. L., Harp, K. L., \& Oser, C. B. (2013). Racial and gender discrimination in the stress process: Implications for African American women's health and well-being. Sociological Perspectives, 56(1), 25-48.

Roper, E. A., \& Halloran, E. (2007). Attitudes toward gay men and lesbians among heterosexual male and female student-athletes. Sex roles, 57(11-12), 919-928.

Ryan, W. S., Legate, N., \& Weinstein, N. (2015). Coming out as lesbian, gay, or bisexual: The lasting impact of initial disclosure experiences. Self and Identity, 14(5), 549-569.

Savin-Williams, R. C. (2005). The new gay teenager. Cambridge, MA: Harvard University Press.

Sidanius, J., \& Pratto, F. (1999). Social dominance: An intergroup theory of social hierarchy and oppression. 10.1017. CBO9781139175043.

Spears Brown, C., \& Bigler, R. S. (2005). Children's perceptions of discrimination: A developmental model. Child development, 76(3), 533-553.

Şahin, N. H., \& Bilgic, D. (2016). Toplumda Eşcinsellere Yönelik Tutumlar ve Lezbiyen Kadınlarda Sağlık Eşitsizliği. Sağhk Bilimleri ve Meslekleri Dergisi, 3(3), 216-225.

Williams, E., Radin, N., \& Allegro, T. (1992). Sex role attitudes of adolescents reared primarily by their fathers: An 11-year follow-up. Merrill-Palmer Quarterly (1982-), 457-476. 